Elsevier required licence: (C) <2019>. This manuscript version is made available under the CC-BY-NCND 4.0 license http://creativecommons.org/licenses/by-nc-nd/4.0/

The definitive publisher version is available online at

[https://www.sciencedirect.com/science/article/pii/S0263237318301427?via\%3Dihub] 


\section{Accounting for the formation of scientific fields in organization studies ${ }^{1}$}

\section{Abstract}

There are few qualitative organizational accounts that explore the constitution of scientific fields in management. We developed a methodology for understanding the academic modes of scientific knowledge production in management research from the perspective of the sociology of scientific knowledge (SSK) and actor-network theory (ANT). SSK and ANT offer a way to account for how scientific fields in organization studies are enacted. Key to this process are splitting and inversion of statements, credibility and network formation, as well as the concepts of credit, trajectory and position. Specific statements making knowledge claims (e.g. handbooks, special editions) are situated in academic practices that obscure those rhetorical strategies that enable the production of a network of knowledge that can act, organizationally, as a more or less unified sub-field. We take as a starting point a collection of texts, dated 2011, which sought to systematize the main currents of a disciplinary sub-field over the last decade, focusing on how statements are transformed into scientific certainty and how the question of credibility is established. The sub-field is that of organizational learning. Organizational learning's particular language relies on epistemic approaches that make its epistemic assumptions intelligible within a network. This language tends to reify and naturalize specific practices that become accredited as organization learning. The material/textual artefacts that sustain these practices, instead of being reified can be reframed as enacting a scientific field whose re-signification acts upon the network that enabled its existence.

Keywords: Management; Organization Studies; Actor Network Theory; Sociology of Scientific Knowledge; Organizational Learning and Knowledge Management; Scientific Fields. 


\section{Introduction}

This paper develops a methodology for understanding the academic modes of production of Management and Organization Studies (MOS), concentrating on a specific sub-field, that of organizational learning (OL) in Brazil, drawing on the sociology of scientific knowledge (SSK) and actor-network theory (ANT) to do so. These approaches are premised on generalized symmetry (Callon, 1986a), recognizing that the social is materially heterogeneous and the material is socially heterogeneous. Knowledge claims are situated in academic practices that obscure those rhetorical strategies that enable them to form as action nets (Czarniawska, 2004) to act as one single - although complex and multiple organizational field. These strategies perform and organize materiality by grouping different materials, translations and mediations of these (Law and Mol, 1995). Accordingly, we draw on "nontraditional data resources" in qualitative research (Bansal \& Corley, 2011, 235) to understand the formation of the sub-field, using a Brazilian OL handbook as data, regarding it as an object of analysis that is itself an organizational artefact.

While the constitution of scientific fields is not a new topic our approach to it is innovative. In the past, to stay only in the modern canon of the social sciences, it is possible to list a huge contingent of authors and theories devoted to the subject - from Kuhn (1962) to the strong program in the sociology of science of Bloor (1981), through the field theory of Bourdieu (1996) and the ethnographic works of Knorr-Cetina (2009). In dealing with the formation of scientific fields, the sociology of science offers systematic studies that suggest the importance of informal communications and relations (cf. Gaston, 1970), social structures (cf. Kuhn, 1970), cognitive and social arrangements (cf. Merton, 1972), inter-personal relations and scientific orientations (cf. Van Rossum, 1973), social systems (cf. Bourdieu, 1996), and knowledge mechanisms and arrangements (cf. Knorr-Cetina, 2009; 2013). 
Handbooks, as well as journals, have had a key role to play in the formation of scientific fields. Special editions of journals, edited collections and handbooks frequently name and demarcate scientific fields from their structured analyses of past and present aspects, focusing on economic, organizational and social change as well as the role played by universities and international journal. In regard to MOS, research that has been collected in Handbooks serves to reflect past aspects of its constitution, in works such as those of Clegg and Hardy (2006), March (1965), and Lorsch (1987). How subfields of MOS, such as Organizational Learning (cf. Easterby-Smith, Crossan, \& Nicolini, 2000), Critical Management Studies (cf. Alvesson, Bridgman, \& Willmott, 2009; Alvesson \& Willmott, 1992) and Organizational Culture (cf. Schein, 1990; Smircich \& Calás, 1987) have been constituted also provide substantive matter for analysis. However, there are few qualitative organizational accounts, apart from bibliometric, sociometric and scientometric mapping or quantitative studies (e.g. Barley, Meyer, \& Gash, 1988; Üsdiken \& Pasadeos, 1995), which explore the constitution of scientific fields in MOS.

This investigation eschews these approaches: instead, it links up with the normativity and politics of SSK and ANT (cf. Law, 2011), offering a methodology for describing symmetrically all organizational (scientific or otherwise) knowledge and fields in the same terms (Bloor, 1986) and without distinguishing humans from non-humans (Callon, 1986a). We adopt an approach to scientific research that does not take sides in order to describe the common world in which we live (Latour, 2013). With (Law, 2010), we regard description as a normative act that arranges phenomena differently. The politics of arrangements, which implies that to describe a phenomenon is to arrange it and that arrangements can be multiple, complex, singular and particular (Law, 2011; Mol, 2002), demonstrates that description is never an innocent practice (cf. Law, 2011; Mol, 2002). 
The article research addresses two main questions: (1) how statements are transformed into scientific certainty? (2) How the question of credibility is established in accounts of organization studies? These questions are more amenable to analysis within the domain of a specific and scientifically demarcated language community than in more open networks. The choice of this analytical framework limits our study to the network of associations triggered by a particular artefact. At the outset, we do not accept the 'naturalness' of those practices of inscription and signification imposed by modern epistemes.. Our investigation constructs a partial and connected representation of organization reality (Strathern 2005) that allows interrogation of the constitutive power of agents, institutions and texts, not as neutral or impartial, so much as elements that "determine what it is to be objective" (Hacking, 1994, 34). To initiate this inquiry, we turn next to academic modes of production.

\section{Academic mode of production of organization analysis}

Management and organization studies construct distinct theoretical objects from mundane experiences. Distinct 'tribes' of practitioners make this construction from differing positions. To understand academic modes of production one should incorporate these differences for it is these that 'manage' knowledge production in a field or sub-field. For some authors, (such as Brown, 1992; Reed, 1992; Fournier \& Gray, 2000), interpretation in organizational research is driven by "interests" (political, ideological, class). Traditionally, such claims' have been countered by urging that organizational analysis should have one 'interest' only: to be objective and value-free (Donaldson, 2010).

The debate is not merely one between protagonists characterized as adherents of 'science' or 'ideology’ (cf. Clegg and Hardy, 2006). According to Brown (1992), it is the complex and multiple associations between academics, institutional arrangements, accredited knowledge and postulated statements that constitute the field of practice. Practice is a populous domain 
constituted by expert knowledge that is institutionalized in how what academic professional doing is represented as being, organized in markets, conducting boundary skirmishes with other professions, postulating the rational-legality of its own positions, and so on. Inasmuch as there are professional fields of practice demarcated within MOS they diverge not only from each other while sharing related family resemblances but also from the knowledge produced on this topic by consultants, administrators and social scientists in general. In skirmishes, it is difficult when caught in the fray not to take sides. One can, however, claim a principled indifference to rival claims (Garfinkel 1967), or seek, agnostically, to practice forms of objectivity that diminish the particularity of interests. Accordingly, the purpose of this paper is to elaborate the dynamics underpinning the modes of scientific knowledge production in one area of MOS, by deploying a combination of SSK and ANT in an innovative way to do so: we annul, in analytical terms, the opinions of scientists about their own work by being agnostic towards them. Our interest is in the material result of authors' activities, in the creation of a Handbook as an epistemic object that serves as the central vector in the fabrication of a particular specialized local organizational knowledge made up in and by practices (Lindberg \& Walter, 2012; Orlikowski and Scott, 2015).

To establish a starting point for analysis we dislocate the primacy that the content of the written text and the subjects seem to have assumed in scientific studies, seeking to recover its material dimension and constitution as a particular network. We enter the discourse constituted by a specific artefact and through it seek to understand how a certain set of national scientific texts can establish a network of material and symbolic associations that contribute to supporting and maintaining theoretical propositions and empirical investments in OL in Brazil. We begin by translating epistemic perspectives into the contemporary world of science studies. 


\section{Translating epistemic perspectives}

For Law (2011), SSK and ANT constitute the two main approaches in science and technology studies (STS). SSK (Collins, 1975; Bloor, 1976) questions the nature of the scientific method and challenges prescriptive epistemological approaches to characterizing the legitimacy of sciences . The principle of symmetry helped Bloor (1976) to understand that different sciences relate to similar practices and should be explained in the same way. ANT, emerging somewhat later as an attempt to recast relations between humans and non-humans in STS, makes the entities involved more equivalent. One of the general principles of the perspective regards being able to understand heterogeneous webs as not always the result of human-centred action. Networks can form around heterogeneous components, enabling the combination of different elements in the construction of scientific (arte)facts (Callon, 1986b; Latour, 1987; Law, 1986a).

ANT and SSK have a common point of interception, in 1979 in the publication of Laboratory Life (Latour and Woolgar, 1979), an ethnographic study of the Salk Institute for Biological Studies. Latour and Woolgar sought to demonstrate that distinctions such as object/subject, facts/artefacts should not be taken as lenses with which to study scientific activity. Instead, statements are translated into becoming facts/artefacts. Latour and Woolgar (1979) argue that for them the principle of symmetry implies explaining nature and society in the same terms rather than seeing them as discrete realms. The impact of this ethnography of life in a laboratory subsequently led to questioning of how scientific facts are constructed. Implications for social and organizational analysis followed. The solidity of the presumed macrostructures of modern social organization could now be seen as the successful translation of the work of micro-actors in their respective local contexts of production (Callon and Latour, 1981). Subsequently, conceptual vocabulary of the period that had been 
dominated by dichotomies was reformed. Three texts that were published in rapid successions led the reform: Les microbes, guerre et paix, suivi de irréductions (Latour, 1984); 'Some elements of a sociology of translation' (Callon, 1986a) and 'On the methods of longdistance control' (Law, 1986a).

For Latour (1984; 1988), by focusing on science as it is (being) done and not on its results, on its practice rather than its moral philosophy, an entirely new field of analysis is configured. The field is centred on practice, on work, constituting ideas that do not arise as mere reflexes of an exercise of abstraction but as the concrete consequence of everyday interactions that are part of the work. Such work involves both humans and non-human heterogeneous artefacts that might, on occasion, be actants. Latour $(1984 ; 1988)$ investigated these diverse agential capacities in the associations between Pasteur, laboratory fermentation of lactic acid and French political society of the nineteenth century, demonstrating how microbes redefined that collective.

Similarly, Callon (1986a) developed research on crustacean farming off the coast of France, where he presents complex sociotechnical networks activated by the joint action of fishermen, scientists and scallops in the production of technological innovations. Callon (1986a) takes into account the entanglement and interaction of materialities, technologies and nonhuman actions. Dialoguing with Bloor's (1976) and Latour and Woolgar's (1979) principles of symmetry, Callon uses the principle of generalized symmetry to describe that how the distinction between beings and things is enacted by means of places, spaces, relationships, translations and networks. Therefore, registers shall not be changed "when we move from the technical to the social aspects of the problem studied" (Callon, 1986a, p. 2). For Callon (1986a), it is the associations of a number of heterogeneous entities (actants) that become articulated in a network. The notion of translation (cf. Serres, 1997), made the use of 
an analytical tool capable of building connections and establishing communication processes possible. As Callon (1986b, p. 26) explained, translation refers to "a definition of roles, a distribution of roles and the delineation of a scenario" that is arbitrarily ordered and always capable of being contested and modified. From Callon's (1986a and b) precursor studies onwards, the notion of translation has afforded a means to access the practice of constructing knowledge, manifesting precarious (dis)ordering mechanisms as a consequence of interactions between materialities and strategies, making feasible the distinction of the heterogeneous parts created and mobilized to overcome resistances and produce organizational effects (Law, 1992), making different words/worlds more or less equivalent (Law, 2009).

Law addressed this debate about ways of building and organizing the social by analysing the role played by modern vessels during the Portuguese voyages of 'discovery' in the passage from the fifteenth to the sixteenth centuries. The maritime expansion that allowed the metropolis in Lisbon long-distance control over its colonies depended on revolutionary navigation systems; in turn, these enabled the alignment of political, economic and social interests with heterogeneous materials. Law (1986a, p. 256) described how ethnographic research should follow the necessary principles of symmetry and relativity "to talk of people, texts and devices in the same analytical terms". Doing so allowed Law (1986b, p. 33) to articulate the notion of networks with (semiotic-material) analysis of modes of organization of power, in which "the pursuit of power, if it is to be carried beyond the face-to-face, has to find materials that possess these properties". Power requires relations; maintaining these relations at a distance requires materialities, which Portuguese innovations in navigation developed. 
Following these precepts this article describes the intellectual networks, translations, strategies, argumentations and logics involved in the construction of a distinct Brazilian OL sub-field, in the context of the international field of Organizational Learning and Knowledge Management (Dierkes, Antal, Child, \& Nonaka, 2001; Easterby-Smith \& Lyles, 2011). The approach that we adopt is certainly an unusual approximation to ANT's suggestion that we investigate scientific activity "in action" (cf. Latour, 1987; Law, 1992). Although seminal actor-network studies did not necessarily developed their studies "in action" (cf. Law, 1986a; Latour, 1987), this study seeks to safeguard something intrinsic to that which ANT proposes. In refusing the literalness and naturalness with which modern epistemologies inscribe their perspectives (Derrida, 1976; Foucault, 1987), we open space for other forms of interpreting that de-epistemologize the supposed nature of knowledge about practices in organization studies. We elaborate an investigative path that aims to restore the agency of the very objects of its production - books, texts and articles. After all, as Strathern (2002) has observed, what must be explained by the contemporary interpretive practices of human knowledge is not so much the background, the nature that would animate all things, so much as the very oscillations that the uniqueness of the thing elicits, even if in a silent way (Monteiro \& Nicolini, 2015). In other words, instead of assuming the context in which a Handbook was devised by its constructors, explaining it as if it were the outcome of an intellectual framework, we demonstrate how this object, once published, can escape the control of its producers, playing "a crucial part in the ongoing construction of action nets" (Lindberg \& Walter, 2012, 4).

We seek to break the binary opposition between writings (inert) and writers (active), repositioning published writings as actants. As Derrida (1976) notes, the practice of destroying the book will enable us to reveal what may be beneath the surface of the text, 
making it possible to break with the usual ways in which the dynamics underpinning the modes of scientific knowledge production are constituted in organizational accounts.

\section{Methods}

\section{Description}

The practice of incorporating SSK/ANT into MOS has been neither homogeneous nor univocal but the result of approximations established over time through dialogues and interpretations that periodically modified the senses of this encounter. For MOS, SSK/ANT are theoretical-methodological perspectives with the potential to unveil and denaturalize the process of building organizational facts and artefacts (cf. Alcadipani and Hassard, 2010). The incorporation of the SSK/ANT repertoire (Mol, 2010) has renewed the ways in which practices are understood and researched in contemporary management. For Czarniawska (2017a and b), research must turn to technology, objects and action nets as equivalents in the construction of the material and social world. For her, the investigation of objects and organizational relationships does not require a priori acceptance of concepts, categories, and organizational typologies. The meta-language of past research interlocutors forming subjects and their understandings of objects of present knowledge and practice should not be used (Latour and Woolgar, 1979) as the observer "cannot simply repeat the analysis suggested by the actors he is studying" (Callon, 1986a, p. 4). To do this is to remain in a recursive hermeneutic circle from which there is no escape.

We offer a qualitative account of the nature of the academic modes of production of organizational analysis, aiming to offer a predominantly descriptive account. A good description contains in itself all the necessary explanation, with the advantage of "offering a disinterested gaze and then being led to action according to the principles discovered by the 
results of the research" (Latour, 2005, p. 257). We take a Brazilian OL handbook as our basic data; thus, the fieldwork consisted in tracing the constitution of the action net by reading and scrutinizing a specific text. Titled Organizational Learning in Brazil, edited by Claudia Simone Antonello and Arilda Schmidt Godoy (2011), with the collaboration of several other experts, the book was the result of a collective effort dedicated to importing new intellectual ideas from within the international network of studies on organizations. ${ }^{2}$ it was a "social artefact" claiming cosmopolitan inclusion but incorporating local particularities constituting "an important milestone in developing a distinctly Brazilian approach to Organizational Learning (OL)" (Araujo, 2011, VIII). Through the agency of the "texts" (Cooren, 2004; Putnam, 2015) comprising this handbook, we "enter" the network of intellectual, professional discursive relationships constituting situational legitimacy. Any starting point must be partial, being only one possible point of projection for a journey. In terms of Brazilian knowledge production, it would be feasible to depart from any national text on organizational learning practices; as an agonistic field in Brazil OL only began to relate its scientific knowledge production, linguistically and nationally, to global challenges in the $2000 \mathrm{~s}$ as formative discourses emerged (cf. Easterby-Smith \& Araujo, 2001; Loiola \& Bastos, 2003; Ruas, Antonello, \& Boff, 2005; Takahashi \& Fischer, 2009; Doyle \& Versiani, 2013).

With Serres (1977), we suggest that studies of science must look into the practical dimension of the various translations that constitute and articulate an object and research context as stable and interdependent realities. Following Latour (2013), we propose that an actant such as a book is a black box inasmuch as it is an effect of the "actor-network" that translates its inscriptions. What any text says can always be interpreted in terms of its positioning and interpellation: the text inscribes a certain kind of practice, composed of persuasive strategies.

Data Collection and Analysis 
From the interpretation of the aforementioned Handbook and its chapters, the data was collected and analysed in an interrelated practice (Corbin, Strauss, \& Strauss, 2014). The data collection sought not to impose any scientific or personal previous knowledge on understanding (cf. Gioia, Corley and Hamilton, 2012), thus bracketing a priori assumptions about ordering practices in the organizational learning field in Brazil. By following the Handbook, accessing multiple actants was possible: articles cited by and that cite the Handbook; past articles; prizes; conferences; debates; CVs of the authors in the Handbook; funding obtained; research topics; discipline syllabi and lists of publications; journals; institutions; structure and dynamic of the local OL action net; national and international researchers and research phenomena.

The initial phase of the research entailed the interpretation of the introductory chapters of Organizational Learning in Brazil, in order to offer a primary and (always) partial description of the polysemic sense of the object denoted. At first, the initial chapters were interpreted as single objects, demonstrating the importance for the Handbook of previous knowledge/articles in the national/international field of OL and of discursive strategies for assigning objectivity to a distinctive local research activity. The Handbook can be described as an actant that constitutes a network, where a network is understood as a methodological term devoid of a priori conceptions (cf. Latour, 1996; 1999; Mol, 2010).

The second phase of the research consisted of analysing the discursive strategy that assigned objectivity and effects of reality to research activity. Henriqson and Kurek's (2011) chapter was chosen for its professions of objectivity, enabling us to demonstrate the material and semiotic conditions that enabled their chapter to act in relationship with and as part of a single Handbook enacting a temporal, specific and local organizational learning network of networks. 
The third and last phase of the research describes the book's academic practices that enable those action nets (Czarniawska, 2004) that create a credible organizational learning field. The specific artefact of the Handbook seeks to establish credibility with its readers and writers. To interpret the trajectory and positions reached by Antonello and Godoy, data were obtained through analysis of the $\mathrm{CV}$ of the organizers, their publications and citations accessed by Google Scholar, applications for funding, papers, research projects, congresses and national scientific journals. Then, the list of names, institutions and research topics developed through a detailed analysis of the CVs of the authors of the Handbook enables us to view the intellectual and professional investment made by the group during the period in which the work was prepared. Specifically, it contrasts the 2010/2011 and the 2016/2017 institutional links, to show the group dynamics after the handbook was released in order to explore the dynamic notion of credibility as a notion of the "costs" expended so that the fabrications of science have "credit", considering the financial, professional and epistemological investments involved (Bourdieu, 1976; Latour \& Woolgar, 1986).

The Handbook is described as part of its author's investment cycle in constituting credibility. Using the notion of network allows us to describe the Handbook as both an arrival and departure point that enacted pathways in the constitution of a national and material framework, reformulating both the position of the authors of the Handbook and others who accepted the book as a starting point in Brazilian Management theory.

\section{The polysemic sense of organizational learning: exploring the Handbook}

The Handbook's Introduction, written by Miguel Pina e Cunha, “The Times they are achanging: the organizational society at the entrance of the XXI century", uses the Bob Dylan title (1964) to symbolize the need to overcome a tradition already established. The work not only introduces different approaches to a common agenda of research problems but also 
places itself positively at the centre of this process, as a privileged agent participating in the intellectual production of this branch of knowledge.

In the first two chapters of the volume, edited by Antonello and Godoy (2011), much backwork weaving of a network into existence is accomplished through historical reconstruction of the main theoretical and methodological perspectives influencing the development of the field. In "Organizational Learning and the roots of its polysemy", we are invited to scroll through the intellectual legacy contributing to the formation of the OL field. According to the authors, traditions that emerged from European and North American management studies in the early 1960s spawned different conceptualizations two decades later, through crossfertilization with areas as diverse as psychology, history, engineering, economics and social sciences. It was the pioneering work of Cyert and March (1963) that, in the 1990s, produced the first significant peak of citations for OL (Crossan \& Guatto, 1996; Prange, 2001) and that the impact of international approaches to OL began to be absorbed in Brazil. The sub-field began to emerge in post-graduate programs and research groups throughout the country. A general stance grounding empirical studies around a "four-dimensional" frame for epistemological learning was delineated. These dimensions were the analytical level (individual or interpersonal); the neutrality of the investigation; organizational change as a topic, and the change processes involved (Antonello \& Godoy, 2011). A network creating local brand affiliations for a scientific specialty was in the process of construction.

In the next chapter, "Cartography of Organizational Learning in Brazil: a multiparadigmatic review", the authors map the strength and the direction that the recent network of OL studies acquired in the country, particularly between 2001 and 2005. From a survey of 96 articles published in four top Brazilian journals and presented at two conferences in the area, a panoramic analysis of the phenomena studied and of the theoretical perspectives mobilized in 
the writings is proposed. A methodological tool that categorized the "field" and its research "themes", through the formulation of "inductive reasoning" was developed to identify certain "patterns, divergent views, contrasts and connections" between the articles (Antonello \& Godoy, 2011, p. 52). Thus, the authors offer a synthetic interpretation of the "diversity" of statements and the "dispersion" of references in the texts investigated. Grouping them into texts having a different "theoretical basis", "perspective on learning" or "paradigm", they translated the conceptual and thematic complexity found in articles by classification premised on other studies in the area.

The classification polarized academic production in the area into two opposing camps: on the one hand, "normative" or "prescriptive" research while, on the other hand, "descriptive" or "neutral" investigations. The split between these two foundational approaches in the field suggested a dispute between a "technical" or "cognitive" flank that would use the concept of "learning organizations" (LO) and other "scientific" terms with which to consider the procedural character of "Organizational Learning" (OL). The split between these two foundational approaches suggested a dispute in which the Handbook assumed a position adjacent to "descriptive" or "neutral" investigations, aligned with the "practice turn" and with descriptive social science studies and methods. These initial chapters must not be assumed to be singular objects if only because they allow heterogeneous elements to become visible (cf. Latour, 1999).

\section{FIGURE 1 ABOUT HERE}

\section{Bifurcated Pathways}

Throughout reading Organizational Learning in Brazil, we note the coexistence of different rhetorical strategies that supported and organized the content of its chapters. In principle, they 
do not differ from what is practiced in other branches of scientific activity. Divided into two parts - Theoretical Aspects: possibilities and impossibilities from the theory and Organizational Learning: possibilities and impossibilities from developed studies - the work built and articulated empirical and conceptual assemblages as representative of Brazilian OL studies. In the first part, containing eight chapters, seven sets of authors presented some of the major theoretical narratives vying for hegemony in the interpretation of the phenomena studied in an attempt to map the main analytical aspects and conceptual trends employed in the past decade. Antonello and Godoy (2011, p. 42) systematize these theoretical and conceptual references for the main disciplinary influences (MOS, Economy, Psychology, Social Sciences) and levels of analysis (Individual Learning, Group Learning, InterOrganizational Learning, Organizational Process) in order to situate the discursive field in which the Handbook, as an action net, sought to insert itself.

The construction and ordering achieved through the analytical tools employed by Antonello and Godoy (2011) does not rely solely on their potential to "reveal" social or cognitive logics. Accepting the social construction of scientific knowledge (Bloor, 1981; Knorr-Cetina, 2013; Latour \& Woolgar, 1986), the assumption of these logics is not the consequence of the empirical universe that they claim to represent, so much as, paradoxically, its cause. By reorganizing the problems and objects surveyed in a sufficiently persuasive language, the categories employed avoid numerous controversies by constituting the Handbook as an artefact providing provisional stability (Lanzara \& Patriotta, 2001). Establishing "safe" realities or "stable" facts substantiates the organization of a whole research network. Next, we will materialize this movement by looking at the levels of analysis and objects exploited by empirical studies as they are distributed in the eighteen chapters of the second part of the Organizational Learning in Brazil collection (see Figure 2). 


\section{FIGURE 2 ABOUT HERE}

As can be seen in Figure 2, the book offers a panoramic view of contemporary investigations. In doing so it suggests the analytical potential of the classification system used. In other words, the organization of texts in the two sections (theoretical and empirical) seeks to persuade readers that the categorical frame mobilized, while representing a synthesis of the efforts of several generations of studies in the field, also operates as a foundation for new studies, as demonstrated by the collection. Once established as validated facts by a network of intellectual endeavour the categories used in the investigation of empirical phenomena split into two distinct entities. On the one side there remains a sequence of words which communicate something probable about a particular object; on the other, these same statements are transformed into independent examples of the phenomena previously established, activating a received grammar already available through the study of related issues.

A learning process in a company differs from the knowledge of administrative practice published in a book or scientific paper because each has distinct modes of existence, historical objects and usages. Academic constructions acquire, enact and produce knowledges through distinct routes, creating specific knowledge paths. Accordingly, in a heterogeneous network of relations, the existence of learning practices and knowledge generated about the knowledge of these practices is maintained, despite their differences, by linkages and nodal points used to produce what is taken to be applied and objective knowledge.

How are statements transformed into scientific certainty? Latour and Woolgar (1986, p. 194) have identified what they call a process of "splitting and inversion" of the significance of scientific statements - a discursive strategy that assigns objectivity and effects of reality to research activity. The operations through which phenomena and their interpretation are 
mutually reinforced abound in the collection. In one chapter in the empirical part, for example, Eder Henriqson and Juliana Kurek (2011) sought to understand how pilots of Brazilian airlines would signify the concepts of Crew Resource Management (CRM), recently established by the local National Aviation Agency (ANAC). The results of this research enable them to confirm that the categories described in the specialized literature ("tacit knowledge" and "explicit knowledge") operate in practice at the "individual" and "collective" levels and compete with the "reflection of practices in action" in the generation of new knowledge - indicating the need for OL studies to adopt a practice-based learning perspective (Perriton \& Hodgson, 2013; Gherardi, 2009; Nicolini, Gherardi, \& Yanow, 2003). Translating from a set of lay categories and analytical perspectives that, in turn, allow for the manufacture of tools and procedures for the collection and analysis of the interviews, Henriqson and Kurek (2011) produce a theoretical and methodological framework to create a certain correspondence between their interpretation of the perceptions of pilots about CRM and what their interpretations revealed.

Henriqson and Kurek (2011) need their "interpretations about" reality and "reality itself" to knit together in correspondence. To that end, they conduct a rhetorical operation that makes the situated speech by the pilots about CRM meanings in aviation distinguishable from discourse about their text addressing the CRM denotations. The immediate implication of this splitting is not only the separation between phenomenon and interpretation but is primarily a reversal in the order of their meanings. Starting as an intellectual construct produced by researchers, the perceptions of the pilots are described tautologically through the redesign or re-enunciation of the narratives that had generated them. It is precisely this inversion in the quality of the enunciations that creates the "illusion" that, in writing about CRM meanings in Brazilian aviation, they are writing about a "real" and "independent" fact: the practices and perceptions of pilots, as they "really" are. 
Once stabilized and accepted as a field, findings acquire some independence from their subjects and undergo a new transformation, making what was a mere "finding" of a particular reality, a fact, becoming the hint of something "deeper", an episteme. At least, that was the way that CRM meanings in aviation were interpreted in a text dedicated to the relationship between "explicit" and "tacit" knowledge in organizational learning - an argument revealed through examination of the learning practices in organizations. That is, through a process of deduction and generalization, interpretation was detached from the context of research to gain a relatively autonomous existence and, with some success, support the construction (theoretical and conceptual) of several other realities.

In looking at the transformation in status of the statements made by Henriqson and Kurek (2011) it is not how they resolved their debates or even if their postulates assumed this or that position that is most significant. Instead, it is their process of theoretical construction that stabilizes a fact in OL, a process as social as the organization practice they describe. The authors of the book, similarly to the administrative practices described within the book, constitute provisional nodal points in a heterogeneous network. That is why, in studying the Handbook, we prioritize the process by which statements are transformed into scientific certainty and facts are socially constructed, not the cognitive operations involved or the validity of their content. Stabilized facts serve as safe starting points for the production of new investigations. Consequently, they also serve to create a whole network of research organized around certain concepts and analytical perspectives whose legitimacy is secured by this practice.

Factual characteristics are generated by means of relations between heterogeneous elements that are not in themselves social (cf. Latour, 2005). The chapter, the Handbook, and the administrative practices they narrate, are heterogeneous points in the network of OL in Brazil 
supporting both practice and theory. Linkages and nodal points that associate previous knowledge and administrative practice produce 'objective' knowledge; however, the objective existence of scientific objects is the consequence and not the cause of research practice if only because empirical objects do not predicate theoretical objects. After all, as Latour and Woolgar indicate (1986, p. 202):

[T]here is nothing especially mysterious about the paradoxical nature of facts. Facts are constructed in such a way that, once the controversy settles, they are taken for granted. (...) The thing and the statement correspond for the simple reason that they come from the same source. Their separation is only the final stage in the process of their construction.

\section{Weaving Network Webs}

Through what Michael Foucault (1978) has defined as the political economy of truth, scientific texts in general offer views that acquire credibility as soon as they can produce the "effect of reality" through their research. Such effects require considerable intellectual and professional investments that the group made during the period in which the work was prepared. We can understand such a social artefact as the end result of a process of convergence of multiple and somewhat random trajectories that end up intertwining ideas, texts, institutions, researchers and research phenomena in a network of relationships created by the very formulation of a "distinctively Brazilian" OL perspective.

\section{Trajectories of the organizers}

The movement undertaken by the organizers of the handbook, in their attempt to generate a local perspective of knowledge production about learning in organizations, can be best understood by analysing the Revista de Administração Comtemporânea (2003), which played 
a key role in the formation of a network of OL studies in Brazil. It did so by publishing a dialogue with respect to disputes around academic accounts of organizational learning in Brazil initiated by Loiola and Bastos (2003a) and replied to by Ruas and Antonello (2003) and to which Loiola and Bastos (2003b) then offered a rejoinder. Shortly thereafter, Ruas, Antonello and Boof (2005) took an editorial stance towards Brazilian OL as an object of study, allowing for formation of credible scientific statements within this aspiring sub-field. Google Scholar provides evidence of this movement ${ }^{3}$ : up until 2002, a search for “Organizational Learning in Brazil” generates one result, a master's dissertation supervised by Roberto Lima Ruas, in Universidade Federal do Rio Grande do Sul (UFRGS). In 2004, in the same university, with the same supervisor, Antonello defended her thesis. Antonello's entry into the learning network in Brazil was made possible through linkages and disputes (Lindberg \& Walter, 2013) constituted by means of complex relationships between journals, rejoinders, previous partnerships and edited books, $\mathrm{PhD}$ scholarships, academic aspirations of young students and supervisors. In 2005, Antonello worked as a management professor at MACKENZIE, about a year before she joined UFRGS as a teacher, where the symbolic beginning of the relationship between her and Arilda Schmidt Godoy began. Antonello was still a relatively unknown researcher on the national scene. Godoy, an educationist with several publications on the teaching of methodologies and research techniques in 2008 held a postdoctoral fellowship in UFRGS. Together, they obtained funding and developed relevant research in OL in Brazil, modifying their individual trajectories. Specifically, Antonello and Godoy developed a survey of OL in Brazil - in two phases (2006-2008) - funded by the Foundation for the State of São Paulo (FAPESP). The partnership, which yielded five articles, made them prominent characters in the rapidly developing OL discipline. From this point of view, Organizational Learning in Brazil may be seen as the culmination of work that reframed the authors' position in Brazilian administration theory. 
Two articles from Antonello and Godoy $(2009 ; 2010)$, which resulted from the survey (20062008), become important for the Handbook and for our research, since they constitute the first two chapters of the work. In the first, Antonello and Godoy (2009), through metatriangulation, selected research sources from expressive/consolidated national journals and congresses of administration/organizational learning (2001-2005), outlining an agenda for studies of OL in Brazil. The second (Antonello and Godoy, 2010), presents a theoretical perspectives that addresses the international field and questions definitions/studies developed in the Brazilian field of OL, questioning levels of analysis, learning outcomes, changes and learning processes to be overcome to make OL significant in Brazil.

Antonello and Godoy $(2009 ; 2010 ; 2011)$ represent an attempt at analysing and creating the conceptual and methodological scaffolding of the local OL field. In doing so, the OL perspective presented to this "distinctively Brazilian" network formed a common agenda of issues, namely: level of learning; neutrality of goals; notions of change; procedural learning and political learning (Antonello \& Godoy, 2010). The authors' practices made it possible to create a national field of OL, in which Brazil could be understood as a recent nodal point constructed in the worldwide agonistic field of OL.

\section{Position of the organizers}

According to Latour and Woolgar (1986), the notion of position is dynamic and relates to the ability to generate (and reinvest) credibility in the field of a specialty so that "recognition" becomes a way to obtain inputs and to increase credibility. Heterogeneous trajectories of authors, universities, disciplines, research groups, empirical phenomena, theories and methodologies became intertwined in the field as forms of recognition. Being recognized, funding for developing longitudinal research, development of new arguments and articles, reading and citations could be produced. Such trajectories, positions, recognitions and their 
conversion into forms of intellectual capital multiply official constructions premising scientific fields.

Once the authors translated their 2009/2010 studies into the first two chapters of the 2011 Handbook, the external and independent existence of a Brazilian field of studies on which further studies could be developed was assumed and affirmed. The impact of Araujo and Cunha, both in their own work and in co-production with established OS authors, also bestowed credibility. The dynamic notion of credibility in Figure 3, specifically contrasts the $2010 / 2011$ and the $2016 / 2017$ institutional links, in order to show that in the years following the book's release, group dynamics changed, modifying and expanding the network structure formed around the postulation of a national field of practice-based studies. ${ }^{4}$

\section{FIGURE 3 ABOUT HERE}

That both space and time dimensions are represented in Figure 3 makes it possible to describe another of the multiple enactments of the book. As an artefact it performs a local network of correlated practices and affordances. For Latour (2007), it is mandatory to understand how a specific instance of objective knowledge is made up and manages to stay alive; as is implicit in Figure 3 the artefact served as a point of departure for many further developments.

Starting research by focusing on objects of multiplicities (Mol, 2002), such as the Handbook, deflects academic endeavour from concentrating on epistemology in order to investigating the possibilities of practice. Drawing on the book as a "nontraditional data resources" in qualitative research (Bansal \& Corley, 2011, p. 235) is but one possible path to knowledge. The book empirically enacts numerous paths to modes of existences, knowledges, perspectives and performances. Nowadays, Google Scholar generates 356 results for “organizational learning in Brazil”. Antonello and Godoy’s (2011) Handbook constitutes one 
of the 356 results, appearing by Google scholar as the most relevant research for the term, having been deployed by 111 citations, prior to July 16, 2018. Citations came from dissertations, course curricula and journals from the fields of administration, international business, medical and multidisciplinary research. These citations represent time and space dimensions of multiple enactments of the book, making it possible to claim that, as an artefact, the book is a social product that is still alive and open (Derrida, 1976). An academic Handbook is a historic object whose meaning constantly evolves as it is socially constructed in institutions, conferences and debates over the years, building credibility for its constructs, becoming departure points for multiple projects.

The associations described in this section, drawn from analysis of the contexts of the collection, certainly do not capture all the underlying relationship of OL studies; they do not even come close to describing what happens in the ninety-six Graduate Programs in Management in Brazil. However, they indicate the construction of a material circuit of power (Clegg, 1989) through which citations and reputations of authors flow, thickened at certain key nodal points, centred on the editors, forming what is now recognized as the OL field in Brazil. It is a discursive place, no doubt, but it is also permeated with traditions of thought, utterance strategies and research procedures consisting of personal relationships and professional networks that house courses, disciplines, lines of research, study groups, funded projects, companies, phenomena of interest and a handful of researchers persuaded to constitute $\mathrm{OL}$ as an eminently scientific rather than normative activity.

Currently, the network is engaged in a vibrant process of expansion in academic areas of Brazilian management theory, broadening their horizons to add new elements to perpetuate the activities of production and consumption of OL knowledge. None of this could be seen or perceived before the network of intellectual relations assembled by Antonello and Godoy 
(2011) materialized in artefacts such as the collection under scrutiny. In other words, it was as if the legitimation of the ideas supported by the collection occurred through the abstract and material connections that the work created after being launched and appreciated by the "academic market". Launched in 2011 by Bookman, publishing in print and electronic formats, one can say that Organizational Learning in Brazil represented a successful politics of knowledge, establishing a certain "state of the art" of the OL discipline in Brazil. In 2012, it won the first place in the Economics, Management and Business category of the $54^{\text {th }}$ Jabuti prize. At present, it is premature to assess the success of the efforts undertaken by the group, particularly because its stability will depend on internal dynamics as well as the ability to ensure perpetuation of the cycle of credibility in the area. Still, it seems reasonable to hypothesize that the investments mobilized in the formulation and articulation of narratives concerning the status of OL in Brazil helped to weave a web of relationships in networks that provided shared meaning to individual careers whose construction was aided by the book.

\section{Discussion}

We have produced a non-conventional actor-network study of a regional academic mode of production in which humans and nonhumans can be seen to weave the threads of network alterities that perform the production of a stable OL field in Brazil. This field, once stabilized, connects local Brazilian academics simultaneously not only to local organizations but also to a global world of OL scholarship. However, as the citations made to the handbook in Google Scholar show, the connection occurs in one direction - outward facing - for that is the nature of epistemic coloniality: the constructs might connect outwards but the direction of trade is basically an import business (Ibarra-Colado, 2006). English language constructs are imported and translated into Brazilian Portuguese characters but are rarely translated in the other direction. 
According to Antonello and Godoy (2011), OL has become distinctly Brazilian because it has enacted a conceptualization that accounts for how academics can approach learning processes in national organizations. Once Antonello and Godoy (2009; 2010; 2011) developed a historical and multi-paradigmatic review of the local agonistic field, deploying a method of meta-triangulation, in their view the Brazilian Organizational Learning field could come to know its own challenges regarding levels, neutrality, change, processual and political learning. Their practices made a national field of OL possible in which the local network is not dislocated from the international web of research and inquiries of learning into practices in organizations. In constituting the Organizational Learning field as part of the field of management in Brazil translation created innovation. As Antonello and Godoy (2011, p. 46) suggest, this new conceptualization forces us to "rethink the methods that should be part of our toolbox"; thus, the concept of OL in Brazil now includes an idea of "practice" while denying "normative" or "prescriptive" studies.

In consonance with Brown (1992), we demonstrated how statements were postulated in the book in order to offer a non-epistemological description of the construction of social reality in organizational learning in the Brazilian field. In presenting the process by which the book could acquire credibility in the local OL field, we provide a value-free description of the authors' practices, concerned with rhetorical mediations and material connections. The interpretation of people in their practices was set aside to focus alternatively on the networks generated from practices and on the action net of statements and relationships making possible an analysis of OL process in Brazil.

As demonstrated, the material web of work enacted by Organizational Learning in Brazil enacts a situated and specific network that includes some authors, practices and institutions, while excluding others. We refer, in particular, to the two opposing groups of research within 
OL in Brazil: a "technical" or "cognitive" thought field, each of which uses the concept of "learning organizations" (LO) and other "scientific" terms to consider the procedural character of "Organizational Learning "(OL) in quite different ways. Organizational Learning in Brazil assumed a position eschewing "normative" or "prescriptive" research in favour of "descriptive" or "neutral" investigations, more in line with the "practice turn" in terms of the split between these two foundational approaches.

The researchers who composed the collection employed a meta-language to explain the meanings of their "application". To avoid the problem of "familiarity" and "strangeness" that polarizes readings cast between "internal" and "external", "applied" or "pure", "incorrect" or "rectified" positions, we have bracketed our particular (epistemological) perspectives in order jointly to track the strength and direction that this specific network acquired to sustain OL theories in Brazil. The nonlinearity of the production of scientific facts is evident in the emerging practice relations that offer alternative ways of researching learning in contemporary organizations in Brazil. With this study, reflexively and recursively, the network researched is enlarged as a possible "path" forwards for organizational researchers of all sorts, as it recognizes that for science the route taken and translated and inscribed is itself knowledge.

\section{Conclusion}

In this paper we developed an innovative way of understanding the academic modes of production of organizational analysis in a specific context bounded by geography and language - Brazil. To do this, we investigated a very particular type of intellectual production that has consolidated in recent decades in the academic field of Administration: the knowledge produced from established scientific knowledge about organizational learning processes. Texts that synthesize the results of certain research activities and postulate 
disciplinary paradigms circulate through Handbooks that inform and at the same time regulate legitimate practices of knowledge production, creating organizational fields (DiMaggio \& Powell, 1983). According to Callon (2002), such knowledge about learning processes is constructed from texts that establish a 'script' for the development of scientific works and a 'scenario' in which the role of academics is specified, encompassing interactions with theoretical categories and formal methodological strategies.

Categorically, the main research contribution is on how epistemological ideals or paradigms are formed, which is only limitedly analysed by special editions of journals, edited collections, quantitative investigations and handbooks that enact a paradigmatic way of seeing organization studies and theories from different assumptions about the nature of social science and society (cf. Burrel \& Morgan, 1979; DiMaggio \& Powell, 1983). However, epistemologies are not neutral scientific activities. The present research demonstrates that a material/textual artefact can be reframed instead of reified. Its re-signification can and must act upon the network that enabled its existence (Law, 2011).

To say that the academic study of OL processes participate in the creation of the realities that one intends to investigate does not mean that the research and knowledge produced by such investigations should be regarded as fanciful inventions. Nor does it mean that the language and the institutional apparatus that supports academic ways of writing about the world are transparent. When we take into account existing conflicts in the current international scene of OL expertise and textual production this is evident. In this case, analysis of the artefacts created in the scientific arena evokes understanding of how local fields learn in a context of scholarly production marked by agnosticism. The public relevance of OL reveals ostensively the ways in which organizations produce significant knowledge in the social world. The present article, however, is made possible by understanding that accumulated knowledge 
about these learning processes not only uses a particular language for expressing the real but also reconstructs this 'real' from perspectives and epistemic approaches that make it intelligible within a production network of knowledge.

To denaturalize such a modus operandi of the area, we have developed this article in relation to the episteme inscribed in the Handbooks that frames the mode of existence of OL in Brazil. Thus, the article demonstrates an academic constitution of national (marginal) and international (central) dimensions that configure a local network that postulates the existence of a single global network of OL and connects to it. Through the Handbook, local studies are translated into the international field and the international field into local studies. In doing so, the local position of the Brazilian network is weakened because it is placed in a situation of epistemic dependence on the supposed centre that it creates by re-knowing its existence. Rather than understanding the epistemological paths activated by the work, we seek to understand how these paths were constructed. Understanding the book as an object that enacts a temporary and situated knowledge, which may be regarded as an always-open construction (Derrida, 1976), prepares the way for a wider analysis of the many Handbooks that have proliferated in various languages in the Organization Studies field in the past twenty years. ${ }^{5}$ Consequently, such an artefact, even as it is coined in a specific textual form, can be reframed and its re-signification act upon the network that enabled its existence.

It seems inevitable, therefore, that we should end these reflections with provocations that may trigger future research: should we really recognize the pre-existence of a global context involving local, national and international networks? Or, on the contrary, are multiple networks of intellectual work competing for space and power in fields of discursive entanglement? Do such networks engage in different modes of ordering? If so, how would 
the associations between the networks be articulated? What makes a network encompassing? In what terms can we describe the differences and similarities between networks?

Paradoxically, analysis of the way Brazilian networks have been organized in recent decades leads us to the image of coordinated margins positioned at a distance from and by intellectual centres of exportation. However, as Czarniawska (2004) and Quattrone and Hopper (2005) teach us, we should not necessarily believe in the pre-existence of a centre that performs

calculations. For this reason, the present article opens a space of resistance to rethink the many paths of this unilateral process that can be availed by other studies that wish to create "critical 'writing in the margin' of every writing that wants to 'center itself on the page"" (Smircich \& Calás, 1987, p. 256).

\section{References}

Alcadipani, R., \& Hassard, J. (2010). Actor-Network Theory, organizations and critique: towards a politics of organizing. Organization, 17(4), 419-435.

Alvesson, M., Bridgman T., \& Willmott H. (eds.) (2009). The Oxford handbook of critical management studies. Oxford Handbooks.

Alvesson, M., \& Willmott, H. (1992). On the idea of emancipation in MOS. Academy of management review 17(3), 432-464.

Antonello, C. S., \& Godoy, A. S. (2009). Uma agenda brasileira para estudos em aprendizagem organizacional. Revista de Administração de Empresas, 49(3), 266-281.

Antonello, C. S., \& Godoy, A. S. (2010). A Encruzilhada da Aprendizagem Organizacional: uma Visão Multiparadigmática/The Crossroads of Organizational Learning: a Multiparadigmatic View. Revista de Administração Contemporânea, 14(2), 310. 
Antonello, C. S., \& Godoy, A. S. (2011). Aprendizagem organizacional no Brasil. Bookman Editora.

Araujo, L. (2011). Apresentação. In C. S. Antonello \& A. S. Godoy (Eds.), Aprendizagem Organizacional no Brasil. Bookman, VitalBook file.

Bansal, P., \& Corley, K. (2011). The coming of age for qualitative research: Embracing the diversity of qualitative methods. Academy of Management Journal 54(2), 233-237.

Bloor, D. (1981). The strengths of the strong programme. Philosophy of the Social Sciences, $11,199-213$.

Bourdieu, P. (1976). Le champscientifique. Actes de la rechercheen sciences sociales, Paris, 2(2), 88-104.

Bourdieu, P. (1996). The rules of art: Genesis and structure of the literary field. Stanford University Press.

Brown, C. (1992). Organization studies and scientific authority. Rethinking organization: new directions in organization theory and analysis, 67-84.

Callon, M. (1986a). Some Elements of a Sociology of Translation: The Domestication of the Scallops and the Fishermen of St. Brieuc Bay. In J. Law (Eds.), Power, Action \& Belief: A New Sociology of Knowledge? London: Routledge \& Kegan Paul.

Callon, M. (1986b). The sociology of an actor-network: The case of the electric vehicle. In Mapping the dynamics of science and technology (pp. 19-34). Palgrave Macmillan, London.

Callon, M. (2002). Writing and (re) writing devices as tools for managing complexity. In J. Law \& A. Mol (Eds.), Complexities: Social Studies of Knowledge Practices (2002), 191-218. 
Callon, M., \& Latour, B. (1981). Unscrewing the big Leviathan: how actors macro-structure reality and how sociologists help them to do so. Advances in social theory and methodology: Toward an integration of micro-and macro-sociologies, 1.

Clegg, S.R. (1989). Frameworks of power. London: Sage.

Clegg, S.R., \& Hardy, C. (2006). Representation and reflexivity. In S.R. Clegg, C. Hardy, W. Nord, and T. Lawrence (Eds.), Handbook of Organization Studies. London: Sage, 423-444

Corbin, J., Strauss, A., \& Strauss, A. L. (2014). Basics of qualitative research. Sage.

Cooren, F. (2004). Textual agency: How texts do things in organizational settings. Organization, 11(3), 373-393.

Crossan, M., \& Guatto, T. (1996). Organizational learning research profile. Journal of Organizational Change Management, 9(1), 107-112.

Cyert, R. M., \& March, J. G. (1963). A behavioral theory of the firm. New Jersey: Englewook Cliffs.

Czarniawska, B. (2017a). Actor-network theory. The SAGE handbook of process organization studies, 160-173.

Czarniawska, B. (2017b). Bruno Latour and Niklas Luhmann as organization theorists. European Management Journal, 2(35), 145-150.

Czarniawska, B. (2004). On time, space, and action nets. Organization, 11(6), 773-791.

Derrida, J. (1976). Of Grammatology. Baltimore: Johns Hopkins University. 
Dierkes, M., Nonaka, I., Child, J., \& Antal, A. B. (2001). Handbook of organizational learning and knowledge. Oxford: Oxford University Press.

DiMaggio, P., \& Powell, W. W. (1983). The iron cage revisited: Collective rationality and institutional isomorphism in organizational fields. American Sociological Review, 48(2), 147160.

Donaldson, L. (2010). The Meta-Analytic Organization: Introducing StatisticoOrganizational Theory. London: M. E. Sharpe.

Doyle, M. L., \& Versiani, A. F. (2013). A produção nacional em aprendizagem organizacional: uma década depois da publicação de Loyola e Bastos. RJ: Enanpad.

Dylan, B. (1964). The times they are a-changing. New York: Columbia (LP).

Easterby-Smith, M., \& Araujo, L. (2001). Aprendizagem organizacional: oportunidades e debates atuais. In Aprendizagem organizacional e organizações de aprendizagem: desenvolvimento na teoria e na prática. São Paulo: Atlas, 15-38.

Easterby-Smith, M., Crossan, M., \& Nicolini, D. (2000). Organizational learning: debates past, present and future. Journal of management studies 37(6), 783-796.

Easterby-Smith, M., \& Lyles, M. (2011). Handbook of organizational learning and knowledge management. UK: Wiley.

Foucault, M. (1978). História da loucura na idade clássica. Tradução de José Teixeira Coelho Netto. 1. ed. SP: Perspectiva.

Foucault, M. (1987). ¿Qué es un autor? Revista de la Universidad Nacional, 2(11), 4-19. 
Fournier, V., \& Grey, C. (2000). At the Critical Moment: Conditions and Prospects for Critical Management Studies. Human Relations, 53(1), 7-32.

Garfinkel, H. (1967). Studies in Ethnomethodology. Inglewood Cliffs, NJ: Prentice Hall.

Gaston, J. (1970). Communication and the reward system of science: A study of a national 'invisible college'. The Sociological Review 18(S1), 25-41.

Gherardi, S. (2009). Introduction: The critical power of the practice lens'. Management learning, 40(2), 115-128.

Hacking, I. (1994). Styles of scientific thinking or reasoning: A new analytical tool for historians and philosophers of the sciences. In Trends in the Historiography of Science, edited by K. Gavroglu, Y. Christianidis, and E. Nicolaidis. Netherlands: Springer, 31-48.

Ibarra-Colado, E. (2006). Organization studies and epistemic coloniality in Latin America: thinking otherness from the margins. Organization, 13(4), 463-488.

Knorr-Cetina, K.D. (2013). The manufacture of knowledge: An essay on the constructivist and contextual nature of science. Elsevier.

Knorr-Cetina, K.D. (2009). Epistemic cultures: How the sciences make knowledge.

Cambridge, MA: Harvard University Press.

Kuhn, T.S. (1962). The structure of scientific revolutions. Chicago: University of Chicago Press.

Lanzara, G.F., \& Patriotta, G. (2001). Technology and the courtroom: An inquiry into knowledge making in organizations. Journal of Management Studies 38(7), 943-971. 
Latour, B. (1984). Les Microbes Guerre Et Paix; Suivi de, Irréductions.

Latour, B. (1987). Science in action: How to follow scientists and engineers through society. Harvard university press.

Latour, B. (1988). The politics of explanation: An alternative. Knowledge and reflexivity: New frontiers in the sociology of knowledge, 10, 155-176.

Latour, B. (1996). On actor-network theory: A few clarifications. Soziale welt, 369-381.

Latour, B. (1999). On recalling ANT. The Sociological Review 47(S1), 15-25.

Latour, B. (2005). Reassembling the social: An introduction to actor-network-theory. Oxford university press.

Latour, B. (2007). A Textbook Case Revisited - Knowledge as mode of existence. In The Handbook of Science and Technology Studies, 3rd edn, edited by E.J. Hackett, O. Amsterdamska, M. Lynch, and J. Wajcman. The MIT Press: 83-112.

Latour, B. (2013). An Inquiry into Modes of Existence. London: Harvard.

Latour, B., \& Woolgar, S. (1986). Laboratory life: the construction of scientific knowledge. New Jersey: Princeton University Press.

Law, J. (1986a). On the methods of long-distance control: vessels, navigation, and the Portuguese route to India. In Power, Action and Belief, edited by J. Law. A New Sociology of Knowledge? London: Routledge and Kegan Paul, 234-263.

Law, J. (1986b). On power and its tactics: a view from the sociology of science. The Sociological Review, 34(1), 1-38. 
Law, J. (1992). Notes on the theory of the actor-network: Ordering, strategy, and heterogeneity. Systemic practice and action research 5(4), 379-393.

Law, J. (2009) Actor network theory and material semiotics. In The new Blackwell companion to social theory, edited by B.S. Turner. Australia: Wiley-Blackwell, 141-158.

Law, J. (2011). Knowledge places. URL $<$ http://www. heterogeneities. net/publications/Law2011KnowledgePlaces. pdf.

Lindberg, K., \& Walter, L. (2013). Objects-in-Use and Organizing in Action Nets: A Case of an Infusion Pump. Journal of Management Inquiry, 22(2), 212-227.

Loiola, E., \& Bastos, A. V. B. (2003a). A produção acadêmica sobre aprendizagem organizacional no Brasil. RAC, 7(3), 181-201, jul./set.

Loiola, E., \& Bastos, A. V. B. (2003b). Ampliando perspectivas para a análise da pesquisa sobre aprendizagem organizacional: uma tréplica. $R A C, 7(3), 213-219$.

Lorsch, J.W. (Eds) (1987). Handbook of organizational behavior. Prentice Hall.

March, J.G. (Eds.) (1965). Handbook of organizations. Chicago: Rand McNally.

Merton, R.K. (1972). Insiders and outsiders: A chapter in the sociology of knowledge. American journal of sociology 78(1), 9-47.

Mol, A. (2002). The body multiple: Ontology in medical practice. Duke University Press.

Mol, A. (2010). Actor-network theory: sensitive terms and enduring tensions. Sonderheft 50, 253-269. 
Monteiro, P., \& Nicolini, D. (2015). Recovering Materiality in Institutional Work: Prizes as an Assemblage of Human and Material Entities. Journal of Management Inquiry, 24(1), 6181.

Nicolini, D., Gherardi, S., \& Yanow, D. (2003). Knowing in organizations: A practice-based approach. ME Sharpe.

Orlikowski, W.J., \& Scott, S.V. (2015). Exploring Material-Discursive Practices. Journal of management studies 52(5), 697-705.

Perriton, L., \& Hodgson, V. (2013). Positioning theory and practice question (s) within the field of management learning. Management Learning, 44(2), 144-160.

Prange, C. (2001). Aprendizagem organizacional: desesperadamente em busca de teorias. In Aprendizagem organizacional e organizações de aprendizagem: desenvolvimento na teoria e na prática, edited by M. Easterby-Smith, J. Burgoyne, and L. Araujo. São Paulo: Atlas, 41-63.

Putnam, L.L. (2015). Unpacking the dialectic: Alternative views on the discourse-materiality relationship. Journal of Management Studies 52(5), 706-716.

Quattrone, P., \& Hopper, T. (2005). A ‘time-space odyssey’: management control systems in two multinational organisations. Accounting, Organizations and Society, 30(7), 735-764.

Reed, M. (1992). Introduction. In Rethinking organization: new directions in organization theory and analysis, edited by M. Reed, and M. Hughes. SAGE, 1-16.

RAC. (2003). vol.7 no.3 Curitiba July/Sept.

Ruas, R., \& Antonello, C. S. (2003). Repensando os referenciais analíticos em aprendizagem organizacional: uma alternativa para análise multidimensional. $R A C, 7(3), 203-212$. 
Ruas, R., Antonello, C. S., \& Boff, L. H. (2005). Os novos horizontes de gestão: aprendizagem organizacional e competências. Bookman Editora.

Schein, E.H. (1990) Organizational culture. American Psychological Association 45(2), 10919

Serres, M. (1977). The Birth of Physics. New York: Clinamen Press.

Smircich, L., \& Calás, M.B. (1987). Organizational culture: A critical assessment. In Handbook of organizational communication: An interdisciplinary perspective, edited by F.M. Jablin, L.L. Putnam, K. Roberts, and L. Porter. Sage Publications, Inc.

Strathern, M. (2002). On space and depth. In Complexities: Social Studies of Knowledge Practices, edited by J. Law, and M. Mol. Durham, NC, and London: Duke University Press, 88-115.

Strathern, M. (2005). Partial connections. Rowman Altamira.

Takahashi, A. R. W., \& Fischer, A. L. (2009). Debates passados, presentes e futuros da aprendizagem organizacional: Um estudo comparativo entre a produção acadêmica nacional e internacional de pessoas. Revista de Administração Mackenzie, 10(5).

Van Rossum, W. (1973). Informal communication and the development of scientific fields. Information. International Social Science Council 12(6), 63-75.

Viveiros de Castro, E. (2014). Cannibal Metaphysics. Minneapolis: Univocal Press.

\footnotetext{
${ }^{1}$ We dedicate this paper to Eduardo Ibarro-Colado. Those familiar with his work will understand why.

${ }^{2}$ Researchers linked to Antonello and Godoy wrote fourteen of the twenty-five chapters. Antonello requested Marco Zimmer, International Association for Continuing Education (AIEC) and Rodrigo Laws, Universidade do Vale do Rio dos Sinos (UNISINOS), to write theoretical essays. Antonello and Luiz Boff - AIEC and
} 
Brazilian Institute of Business Management (IBGEN), LHB information technology and Bank of Brazil wrote another theoretical essay. Antonello also invited seven alumni from Federal University of Rio Grande do Sul (UFRG): Lisiane Closs, professor at Pontifical Catholic University of Rio Grande do Sul (PUC-RS) and IBGEN; Debora Azevedo, professor at UNISINOS; Leonardo Flach, professor at Federal University of Santa Catarina; and Patricia Camillis, who acted as tutor at UFRG. Completing the list were three surveys on the acquisition of knowledge in groups and across organizational groups: Douglas Wegner, a professor at University of Santa Cruz do Sul, Eder Henriqson (who had written together with the engineer Jualiana Kurek), Assistant Professor of UFRG and Luciano Mendes, professor at Federal University of Mato Grosso do Sul. Godoy, in turn, sponsored the entry of alumni from Mackenzie University: Isabel Leite, professor at the Institute of Accounting Research Foundation, Actuarial and Financial and audit superintendent at ABN Amro Real Bank; Daniel Reis, Legislative Assembly of the State of São Paulo; Marcia D'Amelio, Basic Sanitation Company of the State of São Paulo; Lucimara Costa, Mackenzie; and, Diego Rabbit, PUC/SP and Mackenzie.

${ }^{3}$ The research was done and the results were generated in the Portuguese language,

${ }^{4}$ The extensive list of names, institutions and research topics was developed by a detailed analysis of the CVs of the authors, who were linked to the network of contacts of the organizers as the figure below demonstrates, offering a partial but not static view of the academic positions occupied by them in 2010/2011 in contrast with 2016/2017 in the discipline's discursive field.

${ }^{5}$ Reflexively, it should be acknowledged that one of the present authors contributed a number of such Handbooks to the literature; thus knowing in practice that of which we write. 


\begin{tabular}{|c|c|c|c|}
\hline Data Table & Type & Quantity & Use \\
\hline \multirow{6}{*}{$\begin{array}{l}\text { Secondary } \\
\text { Sources }\end{array}$} & $\begin{array}{l}\mathrm{CV} \text { of the authors of } \\
\text { the book }\end{array}$ & $23 \mathrm{CVs}$ & $\begin{array}{l}\text { The CV of the authors allowed for describing } \\
\text { trajectories and positions occupied by them from } 2010 \\
\text { to } 2017 \text {, as well as access academic projects of the } \\
\text { organizers, prizes and requests for funding in relation } \\
\text { to the analysed handbook. }\end{array}$ \\
\hline & Obtained funding & 2 & $\begin{array}{l}\text { It was possible to understand the two initial chapters of } \\
\text { the analysed handbook as the result of a heterogeneous } \\
\text { construction. The initial chapters fundament the whole } \\
\text { handbook structure, which result from the association } \\
\text { of an innovative method for Brazilian organizational } \\
\text { field (metatriangulation), two phases of a long-term } \\
\text { FAESP-funded research project that resulted in } \\
\text { awards, several research articles and bboks / book } \\
\text { chapters, teaching meetings, conferences and academic } \\
\text { presentations. }\end{array}$ \\
\hline & Prizes & 1 & $\begin{array}{l}\text { The Jabuti prize the book was awarded demonstrate } \\
\text { that the book is not only the result of a previous } \\
\text { heterogeneous construction but also a consolidated } \\
\text { departure point, which is both material and rhetorical. }\end{array}$ \\
\hline & Analysed Handbook & 1 & $\begin{array}{l}\text { Throughout it, to access previous knowledge used, } \\
\text { book structure and objectives, authors, relationships, } \\
\text { etc. was possible. }\end{array}$ \\
\hline & Journals & 1 & $\begin{array}{l}\text { RAC played a central role in enacting a web of articles } \\
\text { referring to "organizational learning in Brazil / } \\
\text { aprendizagem organizacional no Brasil". The pivotal } \\
\text { article and the rejoinders were analysed and described } \\
\text { in the text to refer to Antonello's trajectory. }\end{array}$ \\
\hline & Discipline syllabus & 1 & $\begin{array}{l}\text { Universidade Federal do Paraná master in } \\
\text { Management, in the discipline of Organizational } \\
\text { Learning, teacher Adriana R. W. Takahashi, refer to } \\
\text { "RAC. (2003). vol.7 no.3 Curitiba July/Sept" in order } \\
\text { to introduce the field of Organizational Learning in } \\
\text { Brazil. }\end{array}$ \\
\hline
\end{tabular}

Table 1. Information about the use of the data.

Source. Elaborated by the authors. 